\title{
Reduksi Atribut Menggunakan Information Gain untuk Optimasi Cluster Algoritma K-Means
}

\author{
Rozzi Kesuma Dinata ${ }^{\# 1}$, Haried Novriando ${ }^{* 2}$, Novia Hasdyna ${ }^{+3}$, Sujacka Retno ${ }^{+4}$ \\ \#Program Studi Teknik Informatika Universitas Malikussaleh \\ Jl. Medan-Banda Aceh, Cot Teungku Nie, Reuleut, Krueng Geukueh,Kab. Aceh Utara-Aceh \\ ${ }^{1}$ rozzi@unimal.ac.id \\ *Jurusan Informatika Universitas Tanjungpura \\ Jl. Prof. Hadari Nawawi, Pontianak, Kalimantan Barat \\ 2hariedeinformatika.untan.ac.id \\ +Program Studi Teknik Informatika Universitas Islam Kebangsaan Indonesia \\ Jl. Medan-Banda Aceh Sp. Alue Awe, Lhokseumawe, Aceh, Indonesia \\ 3noviahasdyna@gmail.com \\ ${ }^{4}$ sujackaretno@gmail.com
}

\begin{abstract}
Abstrak - Proses clustering dengan algoritma K-Means pada dataset yang memiliki banyak atribut akan mempengaruhi besarnya jumlah iterasi. Pada penelitian ini, metode Information Gain digunakan untuk mereduksi atribut dataset. Dataset yang telah direduksi atribut akan dilanjutkan proses clustering dengan $\mathrm{K}$-Means. Dataset yang dianalisis pada penelitian ini adalah data Hepatitis $C$ Virus yang diperoleh dari UCI Machine Learning Repository, dengan 29 atribut dan 1385 jumlah data. Hasil penelitian ini menunjukkan bahwa rata-rata jumlah iterasi yang diperoleh dari 10 kali pengujian dengan menggunakan K-Means konvensional diperoleh rata-rata sebesar 32 iterasi, sedangkan $\mathrm{K}$-Means dengan reduksi atribut diperoleh ratarata sebesar 27.7 iterasi. Nilai validitas cluster dihitung menggunakan Davies-Bouldin Index (DBI). Nilai DBI pada $K$ Means konvensional sebesar 2.1972, sedangkan DBI pada $K$ Means yang telah direduksi 1 atribut sampai 5 atribut diperoleh nilai rata-rata DBI masing-masing sebesar 2.0290, 1.8771, 1.8641, 1.8389, dan 1.8117.
\end{abstract}

Kata kunci - Reduksi Atribut, Information Gain, K-Means, Davies-Bouldin Index.

\section{Pendahuluan}

Clustering adalah proses pengelompokan objek data menjadi beberapa cluster yang terpisah sehingga data yang ada di dalam masing-masing cluster tersebut menjadi sebuah kelompok data yang memiliki kemiripan yang relatif sama [1]. Ada banyak teknik yang dapat digunakan untuk proses clustering seperti Single Linkage, Complete Linkage, Average Linkage, Fuzzy C-Means, Kohonen SOM, LVQ dan K-Means [2].

Salah satu permasalahan pada proses clustering dengan algoritma $k$-means adalah banyaknya atribut dataset yang menyebabkan bertambahnya jumlah iterasi [3]. Metode seleksi fitur dapat digunakan untuk mereduksi atribut dataset [4]. Pada penelitian ini, metode seleksi fitur yang digunakan adalah Informatin Gain. Metode ini digunakan untuk mereduksi atribut dataset, yaitu satu atribut, dua atribut, tiga atribut, empat atribut dan lima atribut. Setelah direduksi atribut dataset, akan dilanjutkan proses clustering dengan algoritma $k$-means dan selanjutnya akan dianalisis hasil validasi dengan menggunakan Davies-Bouldin Index.

Davies-Bouldin index merupakan salah satu metode yang bertujuan untuk menganalisis peningkatan hasil clustering dengan mengevaluasi besarnya nilai kohesi dan separasi [5].

Pada penelitian data yang akan dianalisis yaitu data Hepatitis C Virus Dataset yang diperoleh dari UCI Machine Learning Repository [6]. Dataset yang direduksi atribut akan dianalisis pengaruhnya terhadap jumlah iterasi dan optimasi hasil evaluasi clustering pada algoritma $k$ means.

\section{Tinjuan Pustaka}

\section{A. Reduksi Atribut Dataset}

Reduksi atribut merupakan proses untuk mengidentifikasi dan menghilangkan atribut dengan nilai yang tidak relevan atau berlebihan [3]. Pada penelitian ini dilakukan seleksi atribut dengan menggunakan Information Gain, selanjutnya dilakukan proses clustering dengan algoritma $k$-means.

\section{B. Information Gain}

Information gain merupakan salah satu metode seleksi fitur yang banyak dipakai oleh peneliti untuk menentukan batas dari kepentingan sebuah atribut [7]. Nilai information gain diperoleh dari nilai entropy sebelum pemisahan dikurangi dengan nilai entropy setelah pemisahan. Pengukuran nilai ini hanya digunakan sebagai tahap awal untuk penentuan atribut yang nantinya akan digunakan atau 
dibuang. Atribut yang memenuhi kriteria pembobotan yang nantinya akan digunakan dalam proses klasifikasi sebuah algoritma [8]. Pemilihan fitur dengan information gain dilakukan dalam 3 tahapan, yaitu:

1. Menghitung nilai information gain untuk setiap atribut dalam dataset original.

2. Tentukan batas (treshold) yang diinginkan. Hal ini akan memungkinkan atribut yang berbobot sama dengan batas atau lebih besar akan dipertahankan serta membuang atribut yang berada dibawah batas.

3. Dataset diperbaiki dengan pengurangan atribut. Pengukuran atribut ini pertama kali dipelopori oleh Claude Shannon didalam teori informasi (Gallager and Fellow2001) serta dituliskan sebagai berikut:

$$
\begin{aligned}
& \operatorname{Entropy}(s)=\sum_{i}^{c}-p_{i} \log _{2} p_{i} \\
& \operatorname{Info}_{A}(D)=-\sum_{j=1}^{v} \frac{D_{j}}{D} \times I\left(D_{j}\right) \\
& \operatorname{Gain}(A)=I(D)-I(A)
\end{aligned}
$$

Keterangan: $\quad$ Gain (A) = Information atribut A

$$
\begin{array}{ll}
\text { I (D) } & =\text { Total entropy } \\
\text { I (A) } & =\text { entropy A }
\end{array}
$$

\section{Algoritma K-Means}

Salah satu metode dalam teknik data mining yang dapat digunakan untuk mengelompokkan data atau Clustering sebuah data kedalam bentuk satu cluster atau lebih cluster adalah $k$-means [9]. Sarwono mengemukakan secara detail, algoritma $K$-Means adalah sebagai berikut yaitu :

1. Tentukan nilai $\mathrm{k}$ sebagai jumlah cluster yang diinginkan.

2. Tentukan nilai acak atau random untuk pusat cluster awal centroid sebanyak $\mathrm{k}$, dengan menggunakan rumus jarak untuk menghitung jarak Euclidean Distance yaitu :

$$
d(x i, \mu j)=\sqrt{\sum_{\mathrm{i}=1}^{\mathrm{n}}(x i-\mu j)^{2}}
$$

Dimana: $\quad x i=$ data kriteria

$$
\mu \mathrm{j}=\text { centroid } \text { pada } \text { cluster } \mathrm{ke}-\mathrm{js}
$$

3. Kelompokkan data berdasarakan nilai jarak terkecil setiap data.

4. Perbaharui centroid baru dari rata-rata cluster dengan persamaan:

$$
\mu j(t+1)=\frac{1}{N s j} \sum_{j \in s j} x j
$$

Keterangan : $\mu \mathrm{j}(\mathrm{t}+1)=$ centroid baru pada iterasi $(\mathrm{t}+1)$ $\mathrm{N} s j=$ Data pada cluster $\mathrm{Sj}$

5. Lakukan perulangan dari langkah 2 hingga 5, sampai anggota tiap cluster tidak ada yang berubah.

\section{Davies-Bouldin Index}

Untuk mengevaluasi hasil cluster pada suatu metode clustering dapat menggunakan metode Davies-Bouldin Index. Landasan dari metode ini adalah nilai kohesi dan separasi [10].

Pada proses clustering, kohesi merupakan jumlah dari kedekatan data terhadap centroid dari cluster yang diikuti. Sedangkan separasi didasarkan pada jarak antar centroid dari cluster tersebut [11].

Langkah-langkah untuk menghitung nilai DaviesBouldin Index adalah sebagai berikut [12]:

1) Sum of Square Within cluster (SSW): Rumus yang digunakan untuk mencari matriks kohesi dalam sebuah cluster ke- $i$ seperti persamaan berikut :

$s S w_{i}=\frac{1}{m i} \sum_{j=1}^{m i} d(x j, c i)$

2) Sum of Square Between cluster (SSB): Sebuah persamaan untuk mengenali fungsi pemisah antar cluster, seperti persamaan berikut [13] :

$S S B i, j=d(c i, c j)$

3) Ratio (Rasio): Memabandingkan nilai cluster i dan cluster $j$, seperti pada persamaan dibawah ini:

$R i j=\frac{S S W i+S S W j}{S S B i j}$

4) Davies-Bouldin Index (DBI): Setelah didapatkan nilai rasio, akan diguunakan untuk mencari nilai DaviesBouldin Index (DBI) dengan rumus berikut [14]:

$D B I=\frac{1}{k} \sum_{i=1}^{k} \max _{i \neq j}\left(R_{i, j}\right)$

Adapun semakin kecil nilai DBI yang diperoleh (nonnegatif $>=0$ ), maka akan semakin baik cluster algoritma $K$ Means [15].

\section{Metoe PENELITIAN}

Framework reduksi atribut dataset dengan Information Gain adalah sebagai berikut.

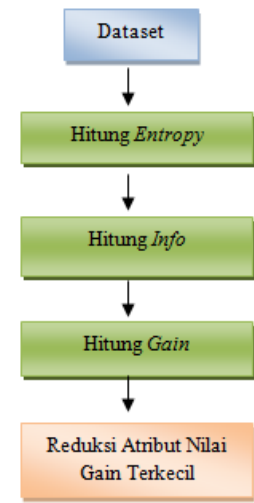

Gambar. 1 Framework proses reduksi atribut dengan information gain 
Adapun nilai gain yang terkecil akan dilakukan proses clustering dengan algoritma $k$-means. Proses reduksi dilakukan sebanyak 5 kali pereduksian. Masing-masing reduksi satu atribut, dua atribut, tiga atribut, empat atribut, sampai lima atribut. Selanjutnya, dianalisis hasil evaluasi clustering dengan DBI untuk mengetahui reduksi atribut data yang paling optimal.

Untuk Framework reduksi atribut dataset dalam optimasi cluster algoritma k-means secara keseluruhan adalah sebagai berikut:

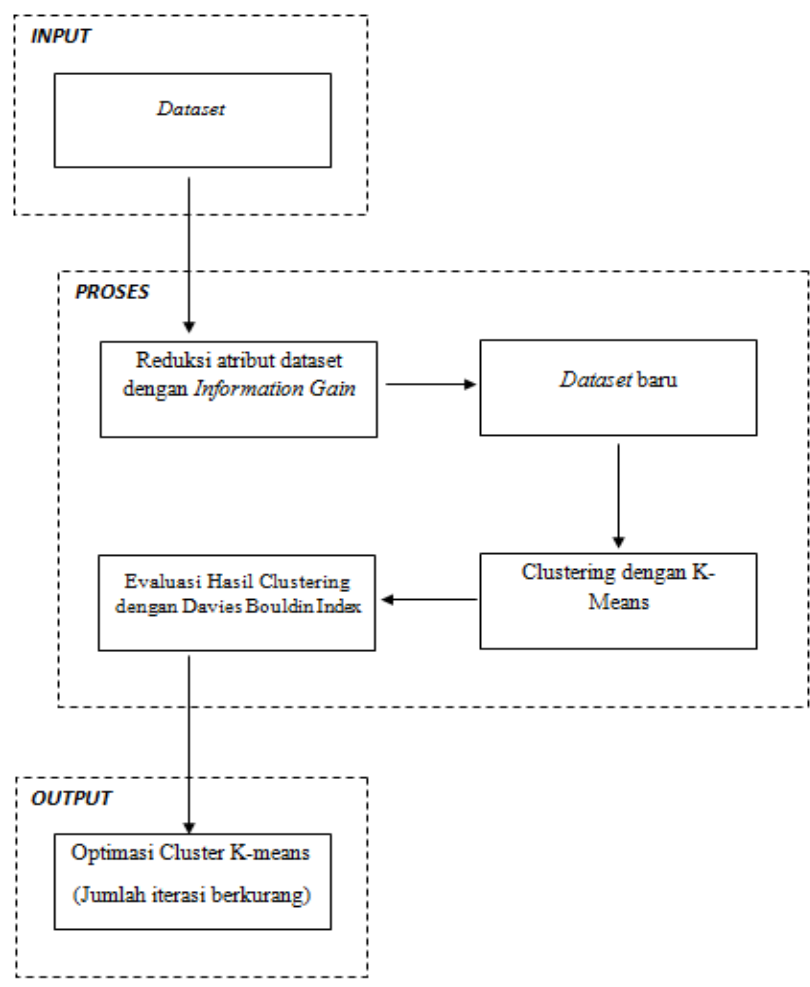

Gambar. 2 Framework penelitian keseluruhan

Berdasarkan gambar diatas, adapun langkah-langkah dalam penelitian ini yaitu:

1. Input Dataset Original.

2. Proses reduksi atribut dengan Information Gain.

3. Pembentukan Dataset baru setelah direduksi.

4. Proses Clustering dengan $K$-means.

5. Evaluasi hasil clustering dengan Davies Bouldin Index.

6. Optimasi Cluster K-Means (Jumlah iterasi berkurang).

\section{HAIL}

\section{A. Nilai Information Gain pada Hepatitis C Virus} Dataset

Berdasarkan persamaan (1), (2), dan (3) diperoleh hasil perhitungan information gain seperti pada tabel 1 .
TABEL I

NILAI INFORMATION GAIN PADA HEPATITIS C VIRUS

\begin{tabular}{|c|c|c|c|}
\hline No & Atribut & $\begin{array}{c}\text { Information } \\
\text { Gain }\end{array}$ & Reduksi \\
\hline 1 & Age & 0,0019881 & \\
\hline 2 & Gender & 0,0034777 & \\
\hline 3 & BMI Body Mass .. & 0,0046983 & \\
\hline 4 & Fever & 0,0011359 & \\
\hline 5 & Nausea/Vomting & 0,0026763 & \\
\hline 6 & Headache & 0,0000891 & Reduksi 1 \\
\hline 7 & Diarrhea & 0,0007394 & \\
\hline 8 & Fatigue \& .. & 0,0010000 & \\
\hline 9 & Jaundice & 0,0019145 & \\
\hline 10 & Epigastric pain & 0,0034203 & \\
\hline 11 & WBC White blood .. & 0,0000943 & Reduksi 2 \\
\hline 12 & RBC red blood cells & 0,0016022 & \\
\hline 13 & HGB Hemoglobin & 0,0011803 & \\
\hline 14 & Plat Platelets & 0,0008341 & \\
\hline 15 & AST 1 aspartate.. & 0,0005072 & \\
\hline 16 & ALT 1 alanine .. & 0,0011256 & \\
\hline 17 & ALT 4 alanine.. & 0,0010269 & \\
\hline 18 & ALT 12 alanine .. & 0,0004240 & Reduksi 5 \\
\hline 19 & ALT 24 alanine .. & 0,0002474 & Reduksi 4 \\
\hline 20 & ALT 36 alanine .. & 0,0001732 & Reduksi 3 \\
\hline 21 & ALT 48 alanine.. & 0,0004936 & \\
\hline 22 & ALT after 24 w.. & 0,0027067 & \\
\hline 23 & RNA Base & 0,3361371 & \\
\hline 24 & RNA 4 RNA 4 & 0,3679658 & \\
\hline 25 & RNA 12 RNA 12 & 0,0026596 & \\
\hline 26 & RNA EOT .. & 0,0004377 & \\
\hline 27 & RNA EF RNA .. & 0,0041398 & \\
\hline 28 & Baseline histological & 0,0006377 & \\
\hline 29 & Baseline staging & 0,0167970 & \\
\hline
\end{tabular}

Berdasarkan tabel 1, dapat dijabarkan dalam bentuk diagram berikut.

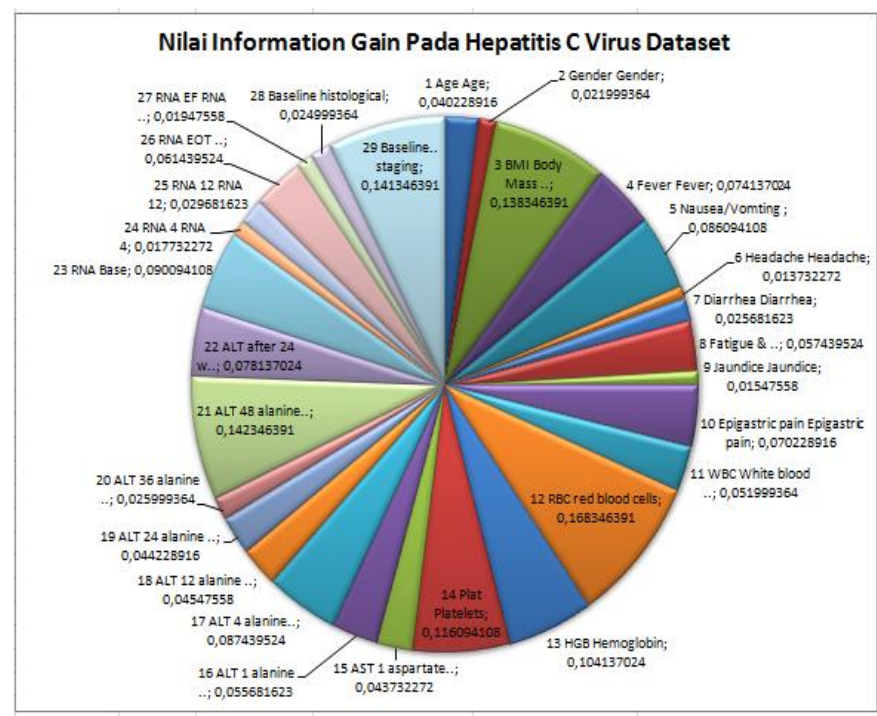

Gambar. 3 Diagram hasil information gain pada hepatitis $\mathrm{C}$ virus dataset

Nilai information gain terkecil adalah atribut ke-6, kedua adalah atribut ke-11, ketiga adalah atribut ke-20, reduksi keempat adalah atribut ke-19, dan reduksi kelima adalah atribut ke-18. Adapun pada penelitian ini, atribut yang direduksi adalah atribut dengan nilai information gain 
terkecil. Proses pereduksian dengan reduksi satu atribut, dua atribut, tiga atribut, dan empat atribut. Selanjutnya akan di analisis hasil komparasinya dengan DBI.

\section{B. Proses Clustering dengan K-Means}

Hasil perhitungan clustering dengan algoritma $k$-means dengan reduksi atribut dapat dilihat pada tabel 1, atribut Headache $\left(x_{6}\right)$ direduksi karena memperoleh nilai Information Gain terkecil sebesar 0.0000891. Pada pengujian kali ini dilakukan sebanyak 10x pengujian yang diperlihatkan pada tabel 2 berikut:

TABEL III

Pengujian K-MEANs CLUSTERING DENGAN REDUKSi SATU ATRIBUt

\begin{tabular}{|c|c|c|}
\hline \multirow{2}{*}{ Pengujian } & \multicolumn{2}{|c|}{ Iterasi } \\
\cline { 2 - 3 } & $\begin{array}{c}\text { Konvensional } \\
\text { K-Means }\end{array}$ & $\begin{array}{c}\text { K-Means } \\
+ \\
\text { Reduksi 1 }\end{array}$ \\
\hline 1 & 37 & 30 \\
\hline 2 & 32 & 26 \\
\hline 3 & 29 & 33 \\
\hline 4 & 33 & 32 \\
\hline 5 & 25 & 28 \\
\hline 6 & 38 & 30 \\
\hline 7 & 33 & 30 \\
\hline 8 & 30 & 31 \\
\hline 9 & 35 & 30 \\
\hline 10 & 28 & 35 \\
\hline Rata-rata & 32 & 30,5 \\
\hline
\end{tabular}

Berdasarkan Tabel 2, pengujian $K$-Means konvensional memperoleh jumlah iterasi terbesar untuk menyelesaikan proses clustering sebesar 38 iterasi, pada pengujian ke 5 diperoleh jumlah iterasi terendah sebesar 25 iterasi. Sedangkan menggunakan $K$-Means dengan mereduksi satu atribut diperoleh jumlah iterasi terbesar pada pengujian ke 10 sebesar 35 iterasi, pada pengujian ke 2 diperoleh jumlah iterasi terendah sebesar 26 iterasi.

Rata-rata jumlah iterasi yang diperoleh dari masingmasing 10x pengujian dengan menggunakan $K$-Means konvensional diperoleh rata-rata sebesar 32 iterasi, sedangkan dengan $k$-means dengan reduksi satu atribut diperoleh rata-rata sebesar 30.5 iterasi.

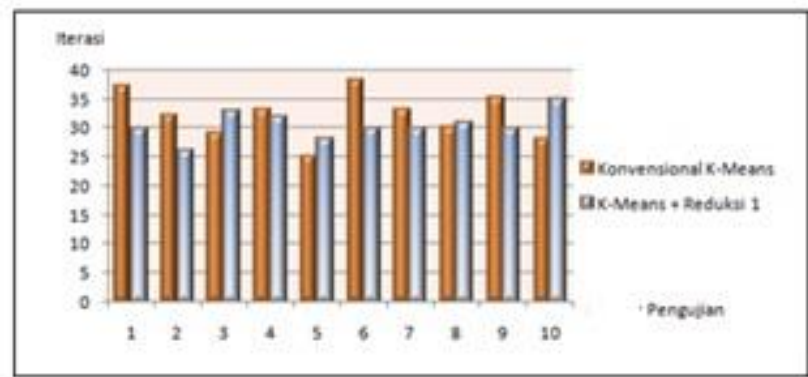

Gambar. 4 Grafik hasil clustering k-means dengan reduksi satu atribut

Atribut Headache $\left(x_{6}\right)$ dan WBC White Blood Cell $\left(x_{11}\right)$ direduksi karena memperoleh nilai Information Gain 2 terkecil masing-masing sebesar 0.0000891 dan 0.0000943 . Pada pengujian kali ini dilakukan sebanyak 10x pengujian yang diperlihatkan pada tabel 3 berikut:
TABEL IIIII

PenguJian K-MEANS CLUSTERING DENGAN REDUKSi DuA ATRIBUT

\begin{tabular}{|c|c|c|}
\hline \multirow{2}{*}{ Pengujian } & \multicolumn{2}{|c|}{ Iterasi } \\
\cline { 2 - 3 } & $\begin{array}{c}\text { Konvensional } \\
\text { K-Means }\end{array}$ & $\begin{array}{c}\text { K-Means + } \\
\text { Reduksi 2 }\end{array}$ \\
\hline 1 & 37 & 31 \\
\hline 2 & 32 & 25 \\
\hline 3 & 29 & 30 \\
\hline 4 & 33 & 37 \\
\hline 5 & 25 & 29 \\
\hline 6 & 38 & 30 \\
\hline 7 & 33 & 25 \\
\hline 8 & 30 & 30 \\
\hline 9 & 35 & 31 \\
\hline 10 & 28 & 31 \\
\hline Rata-rata & 32 & 29,9 \\
\hline
\end{tabular}

Berdasarkan Tabel 3, pada pengujian K-Means konvensional memperoleh jumlah iterasi terbesar untuk menyelesaikan proses clustering sebesar 38 iterasi, pada pengujian ke 5 diperoleh jumlah iterasi terendah sebesar 25 iterasi. Sedangkan menggunakan K-Means dengan mereduksi dua atribut diperoleh jumlah iterasi terbesar pada pengujian ke 4 sebesar 37 iterasi, pada pengujian ke 2 dan ke 7 diperoleh jumlah iterasi terendah sebesar 25 iterasi.

Rata-rata jumlah iterasi yang diperoleh dari masingmasing 10x pengujian dengan menggunakan K-Means konvensional diperoleh rata-rata sebesar 32 iterasi, sedangkan dengan $k$-means dengan reduksi dua atribut diperoleh rata-rata sebesar 29.9 iterasi.

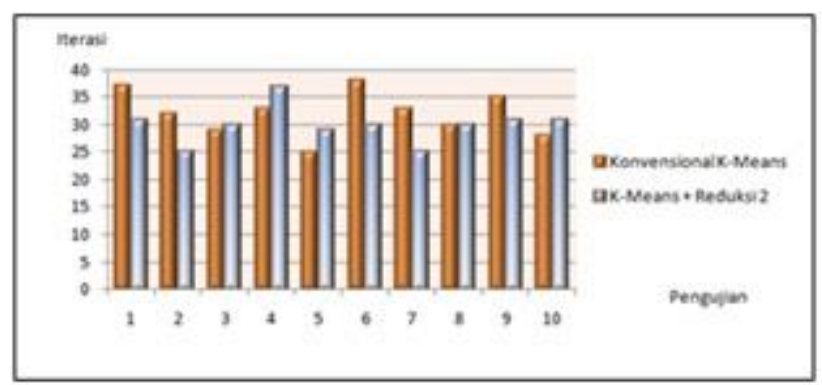

Gambar. 5 Grafik hasil clustering k-means dengan reduksi dua atribut

Atribut Headache $\left(x_{6}\right)$, WBC White Blood Cell $\left(x_{11}\right)$ dan ALT 36( $\left.x_{20}\right)$ direduksi karena memperoleh nilai Information Gain 3 terkecil masing-masing sebesar $0.0000891,0.0000943$ dan 0.0001732 .

Berdasarkan tabel 4, pada pengujian K-Means konvensional memperoleh jumlah iterasi terbesar untuk menyelesaikan proses clustering sebesar 38 iterasi, pada pengujian ke 5 diperoleh jumlah iterasi terendah sebesar 25 iterasi. Sedangkan menggunakan K-Means dengan mereduksi tiga atribut diperoleh jumlah iterasi terbesar pada pengujian ke 8 sebesar 33 iterasi, pada pengujian ke 6 diperoleh jumlah iterasi terendah sebesar 25 iterasi.

Rata-rata jumlah iterasi yang diperoleh dari masingmasing 10x pengujian dengan menggunakan K-Means konvensional diperoleh rata-rata sebesar 32 iterasi, sedangkan dengan $k$-means reduksi tiga atribut diperoleh rata-rata sebesar 29.1 iterasi. Pengujian diperlihatkan pada tabel 4 berikut: 
TABEL IVV

PENGUJiAn $K$-MEANS CLUSTERING DENGAN REDUKSI Tiga ATRIBUT

\begin{tabular}{|c|c|c|}
\hline \multirow{2}{*}{ Pengujian } & \multicolumn{2}{|c|}{ Iterasi } \\
\cline { 2 - 3 } & $\begin{array}{c}\text { Konvensional } \\
\text { K-Means }\end{array}$ & $\begin{array}{c}\text { K-Means + } \\
\text { Reduksi 3 }\end{array}$ \\
\hline 1 & 37 & 28 \\
\hline 2 & 32 & 29 \\
\hline 3 & 29 & 30 \\
\hline 4 & 33 & 30 \\
\hline 5 & 25 & 31 \\
\hline 6 & 38 & 25 \\
\hline 7 & 33 & 28 \\
\hline 8 & 30 & 33 \\
\hline 9 & 35 & 29 \\
\hline 10 & 28 & 28 \\
\hline Rata-rata & 32 & 29,1 \\
\hline
\end{tabular}

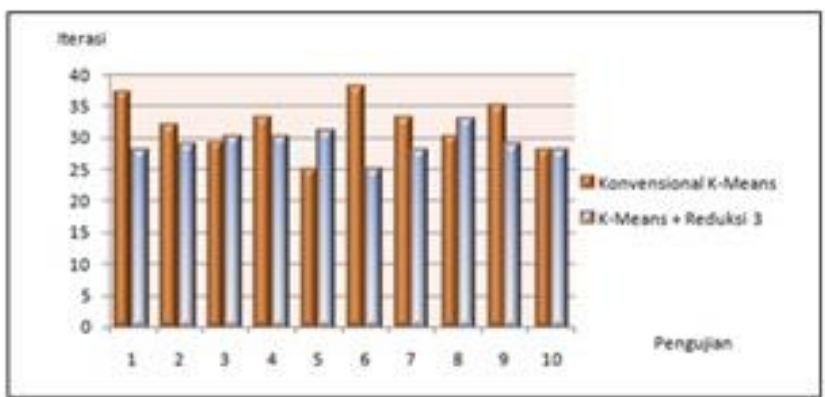

Gambar. 6 Grafik hasil clustering k-means dengan reduksi tiga atribut

Atribut Headache $\left(x_{6}\right)$, WBC White Blood Cell $\left(x_{11}\right), A L T$ $36\left(x_{20}\right)$ dan $A L T 24\left(x_{19}\right)$ direduksi karena memperoleh nilai Information Gain 4 terkecil masing-masing sebesar $0.0000891, \quad 0.0000943, \quad 0.0001732$ dan 0.0002474 . Pengujian kali ini dilakukan sebanyak 10x pengujian diperlihatkan pada tabel 5 berikut:

TABEL V

Pengujian $K$-MEANS CLUSTERING DENGAN REDUKSi EMPAT ATRIBUT

\begin{tabular}{|c|c|c|}
\hline \multirow{2}{*}{ Pengujian } & \multicolumn{2}{|c|}{ Iterasi } \\
\cline { 2 - 3 } & $\begin{array}{c}\text { Konvensional } \\
\text { K-Means }\end{array}$ & $\begin{array}{c}\text { K-Means + } \\
\text { Reduksi 4 }\end{array}$ \\
\hline 1 & 37 & 30 \\
\hline 2 & 32 & 26 \\
\hline 3 & 29 & 24 \\
\hline 4 & 33 & 31 \\
\hline 5 & 25 & 27 \\
\hline 6 & 38 & 30 \\
\hline 7 & 33 & 25 \\
\hline 8 & 30 & 30 \\
\hline 9 & 35 & 30 \\
\hline 10 & 28 & 27 \\
\hline Rata-rata & 32 & 28 \\
\hline
\end{tabular}

Berdasarkan Tabel 5, pada K-Means konvensional memperoleh jumlah iterasi terbesar untuk menyelesaikan proses clustering sebesar 38 iterasi, pada pengujian ke 5 diperoleh jumlah iterasi terendah sebesar 25 iterasi, sedangkan menggunakan K-Means dengan mereduksi empat atribut diperoleh jumlah iterasi terbesar pada pengujian ke 4 sebesar 31 iterasi, pada pengujian ke 3 diperoleh jumlah iterasi terendah sebesar 24 iterasi.
Rata-rata jumlah iterasi yang diperoleh dari masingmasing 10x pengujian dengan menggunakan K-Means konvensional diperoleh rata-rata sebesar 32 iterasi, sedangkan dengan $k$-means reduksi empat diperoleh ratarata sebesar 28 iterasi.

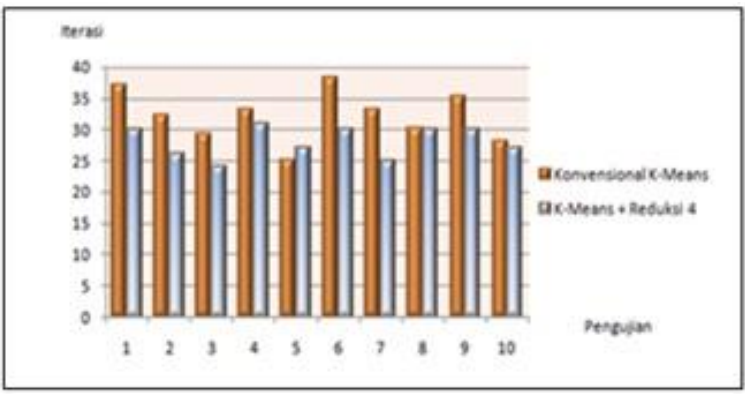

Gambar. 7 Grafik hasil clustering k-means dengan reduksi empat atribut

Atribut Headache ( $\left.x_{6}\right)$, WBC White Blood Cell $\left(x_{11}\right), A L T$ $36\left(x_{20}\right), A L T 24\left(x_{19}\right)$ dan ALT 12( $\left.x_{18}\right)$ direduksi karena memperoleh nilai Information Gain 5 terkecil masingmasing sebesar 0.0000891, 0.0000943, 0.0001732, 0.0002474 dan 0.0004240 . Pada pengujian kali ini dilakukan sebanyak 10x pengujian diperlihatkan pada tabel 6 berikut:

TABEL VI

PENGUJian $K$-MEANS CLUSTERING DENGAN REDUKSI LIMA ATRIBUT

\begin{tabular}{|c|c|c|}
\hline \multirow{2}{*}{ Pengujian } & \multicolumn{2}{|c|}{ Iterasi } \\
\cline { 2 - 3 } & $\begin{array}{c}\text { Konvensional } \\
\text { K-Means }\end{array}$ & $\begin{array}{c}\text { K-Means + } \\
\text { Reduksi 5 }\end{array}$ \\
\hline 1 & 37 & 28 \\
\hline 2 & 32 & 29 \\
\hline 3 & 29 & 28 \\
\hline 4 & 33 & 25 \\
\hline 5 & 25 & 30 \\
\hline 6 & 38 & 25 \\
\hline 7 & 33 & 28 \\
\hline 8 & 30 & 25 \\
\hline 9 & 35 & 26 \\
\hline 10 & 28 & 33 \\
\hline Rata-rata & 32 & 27,7 \\
\hline
\end{tabular}

Berdasarkan Tabel 6, pada pengujian K-Means konvensional memperoleh jumlah iterasi terbesar untuk menyelesaikan proses clustering sebesar 38 iterasi, pada pengujian ke 5 diperoleh jumlah iterasi terendah sebesar 25 iterasi. Sedangkan menggunakan K-Means dengan mereduksi lima atribut diperoleh jumlah iterasi terbesar pada pengujian ke 10 sebesar 33 iterasi, pada pengujian ke 4, 6 dan 8 diperoleh jumlah iterasi terendah sebesar 25 iterasi.

Rata-rata jumlah iterasi yang diperoleh dari masingmasing 10x pengujian dengan menggunakan $K$-Means konvensional diperoleh rata-rata sebesar 32 iterasi, sedangkan dengan $k$-means reduksi lima atribut iperoleh rata-rata sebesar 27.7 iterasi, seperti grafik dibawah ini. 


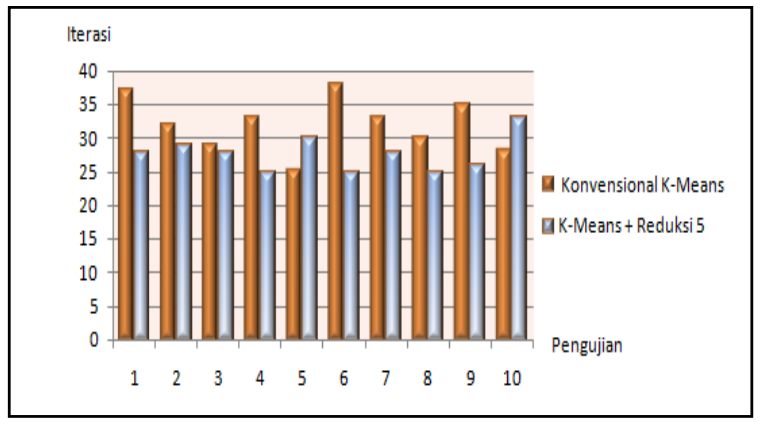

Gambar. 8 Grafik hasil clustering k-means dengan reduksi lima atribut

\section{Nilai Davies-Bouldin Index (DBI)}

Hasil perhitungan nilai DBI pada $K$-Means konvensional dengan $K$-Means yang direduksi atribut dapat dilihat pada tabel komparasi berikut:

TABEL VII

KOMPARASI NILAI DBI

\begin{tabular}{|c|c|c|c|c|c|}
\hline \multicolumn{5}{|c|}{ Nilai Davies-Bouldin Index (DBI) } \\
\hline \multirow{2}{*}{ K-Means } & 1 & 2 & 3 & 4 & 5 \\
\cline { 2 - 6 } & $1.82 a n s$ + Reduksi Atribut \\
\hline 2.1972 & 2.0290 & 1.8771 & 1.8641 & 1.8389 & 1.8117 \\
\hline
\end{tabular}

Berdasarkan tabel 7, nilai DBI pada $k$-means konvensional sebesar 2.1972, sedangkan DBI pada K-Means yang telah direduksi 1 atribut sampai 5 atribut diperoleh nilai DBI masingmasing sebesar 2.0290, 1.8771, 1.8641, 1.8389, dan 1.8117, seperti pada grafik dibawah ini.

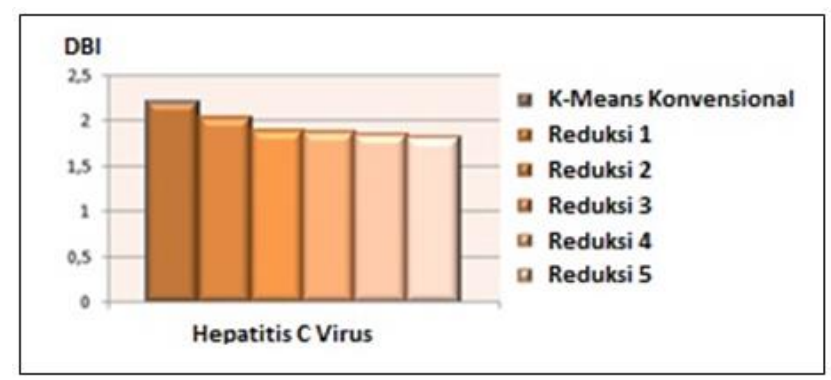

Gambar. 9 Grafik komparasi nilai DBI

\section{KESIMPULAN}

Berdasarkan hasil penelitian yang telah dilakukan, metode reduksi atribut Information Gain mampu mengoptimasi cluster algoritma $k$-means. Nilai evaluasi clustering Davies Bouldin Index terbaik adalah pada reduksi atribut ke lima sebesar 1,8117. Adapun nilai DBI pada $k$-means sebelum direduksi atribut adalah sebesar 2,1972. Hasil penelitian ini juga menunjukkan bahwa metode Information Gain dapat mengurangi jumlah iterasi pada proses clustering $K$-Means., dengan rata-rata jumlah iterasi pada $K$-Means sebelum direduksi adalah 32 iterasi. Rata-rata jumlah iterasi pada $K$-Means dengan reduksi satu sampai lima atribut adalah sebesar 27,7 iterasi.

\section{REFERENSI}

[1] A. Singh, A. Yadav, A. Rana, "K-Means with Three different Distance Metrics". IJCA, S, , Vol No 10, 2013.67,

[2] N. Arunkumar, M. A. Mohammed, M. K .A Ghani, D. A. Ibrahim, "K-means clustering and neural network for object detecting and identifying abnormality of brain tumor". Soft Computing, 2019, 23.19: $9083-9096$.

[3] A. Bates, J. Kalita, "Counting Clusters in Twitter Posts", Proceedings of the 2nd International Conference on Information Technology for Competitive Strategies, 2016, pp, 85.

[4] B. J. D. Sitompul, "Peningkatan Hasil Evaluasi Cluster DaviesBouldin Index Dengan Penentuan Titik Pusat cluster awal Algoritma K-Means", Universitas Sumatera Utara, 2018.

[5] V. Chandani, R.S. Wahono, "Komparasi algoritma klasifikasi Machine Learning dan feature selection pada analisis sentimen review film”. Journal of Intelligent Systems, 2015, 1.1: 56-60.

[6] M. Bora, D. Jyoti, D. Gupta, A. Kumar, "Effect of Different Distance Measures on the Performance of K-Means Algorithm: An Experimental Study in Matlab", IJCBIT, Vol 5, No 2, 2014

[7] E. Dabaghi, H. Kashanian, "Feature dimension reduction of multisensor data fusion using principal component fuzzy analysis". International Journal of Engineering, 2017, 30.4: 493-499.

[8] D. Abdullah, "Determining a Cluster Centroid of K-Means Clustering Using Genetic Algorithm", IJCSSE, 4(6), 2015,160-164

[9] O. J. Oyelade, O. O. Oladipupo, I. C. Obagbuwa, "Application of K-Means Clustering Algorithm for Prediction of Students's Academic Performance", IJCSIS, Vol 7, No 1, 2010.

[10] E. Prasetyo, "Reduksi Dimensi Set Data dengan DRC pada Metode Klasifikasi SVM dengan Upaya Penambahan Komponen Ketiga", Prosiding SNATIF, 2014, 293-300.

[11] P. M. Shakeel, S. Baskar, V. R. S. Dhulipala, "Cloud based framework for diagnosis of diabetes mellitus using K-means clustering", Health information science and systems, 2018, 6.1: 16.

[12] T. Silwattananusarn, K. Tuamsuk, "Data Mining and Its Applications for Knowledge Management: A Literature Review from 2007 to 2012", IJDKP, Vol 2, No 5, 2012.

[13] U. R. Raval, C. Jani, "Implementing \& Improvisation of $K$-means Clustering Algorithm”, IJCSMC, Vol 5, 191203, Issue 5, 2016.

[14] Y. F. Waruwu, M. Zarlis, E. B. Nababan, "Seleksi Atribut Pada Algoritma Radial Basis Function Neural Network Menggunakan Information Gain”, Seminar Nasional Royal (SENAR), Vol. 1, No. 1, 2018, pp. 21-24.

[15] Q. Zhan, "An Improved K-Means Algorithm Based on Structure Features", Journal of Software, Vol 12, No 1, 2017. 